\title{
The Role of Confucian Education in Vietnamese Society in the Mac Dynasty
}

\author{
Dr. Pham Thi Quynh \\ Hanoi National University of Education, Viet Nam
}

\begin{abstract}
Summary
The Confucian education of the Mac dynasty ${ }^{1}$, besides its great achievements, also contributed significantly to the stagnation in economy, science and technology, as well as negative thoughts that were still deeply rooted in the perception of people in Vietnam. Today's era is far different from the Mac era, so besides the positive values that can be inherited and promoted, there are still a lot of inadequacies, outdated, inappropriate, even possible. become a hindrance to the cause of Vietnamese education today. That is also the reason why we must have a dialectical point of view when studying back to the traditional Confucian education to see its significance in the development of Vietnamese education today. This is also a prerequisite for building an advanced education, imbued with national identity with the noble purpose of training people who are fully developed, have enough virtue, enough talent, participate in winning force into the construction and defense of the socialist Vietnamese Fatherland.
\end{abstract}

Keywords: Mac dynasty, Confucian education, Vietnamese history, Mac Thai To, Hau le dynasty.

DOI: $10.7176 / \mathrm{JPCR} / 54-02$

Publication date:July $31^{\text {st }} 2021$

\section{Preamble}

The Mac Dynasty is a feudal dynasty in Vietnamese history, starting when King Mac Thai To ascended the throne in June 1527 after taking power from King Le Cung Hoang of the $\mathrm{Hau} \mathrm{Le}^{2}$ dynasty and ending when King Mac Mau Hop was overthrown. The Le - Trinh army led by Trinh Tung defeated at the end of 1592. However, the remnants of the Mac dynasty such as Mac Kinh Cung, Mac Kinh Khoan, and Mac Kinh Vu still continued to oppose the Hau Le dynasty during the medieval period. until 1677 in the Cao Bang area. The period 1527-1592 in Vietnamese history is also known as the Southern - Northern dynasties period, because the Mac government only really had power from present-day Ninh Binh territory, and from Thanh Hoa onwards on the list. meaning is in the hands of the Le kings. During the formation and development of Vietnam's feudal society, starting from the Ly dynasty, the feudal dynasties chose Confucianism, taking Confucian education as a formal education, in order to use Confucianism as a formal education. using Confucianism as an ideology, as a tool to govern and manage society. But it was not until the $\mathrm{Le} \mathrm{So}^{3}$ period - the heyday of the national feudal system, that education and examinations really went into strict discipline. After the Mac dynasty replaced the Le dynasty to rule the country (1527), in order to build and maintain the dynasty, there was no other way for the Mac dynasty to consolidate and build education and training in the spirit of Confucianism. Therefore, during the reign of the Mac Dynasty (1527 - 1592), although the country was in turmoil and war was constant, studying and taking exams was still paid special attention by the court. During the more than 60 years of regularly opening examinations, the Mac dynasty has organized 22 Dinh exams. Since then, Confucianism has more and more conditions to influence many aspects and areas of Vietnamese social life and people and play a certain role in the process of formation and development of society. Vietnamese feudalism. However, in Vietnam's feudal history, the Mac dynasty was considered a puppet dynasty by feudal historians, so they did not pay attention to recording and preserving historical documents about that dynasty. there is a "additional note" about the Mac family.

\footnotetext{
${ }^{1}$ The Mac Dynasty is a monarchy in Vietnamese history, beginning when Mac Dang Dung forced King Le Cung Hoang to cede the throne in June 1527 and ended when King Mac Mau Hop established his son Mac Toan to the throne. was defeated by the army of Le-Trinh led by Trinh Tung in February 1593. Mac Toan then ascended the throne but was only in office for 2 months, the total official duration of the dynasty was nearly 66 years. However, in the later period, descendants of the Mac dynasty such as Mac Kinh Chi, Mac Kinh Cung, Mac Kinh Khoan, Mac Kinh Vu, Mac Kinh He, and Mac Kinh Quang still continued to oppose the Later Le dynasty during the medieval period until the end.

${ }^{2}$ The Later Le Dynasty was a Vietnamese feudal dynasty that existed after the 4th Northern colonial period and concurrently with the Mac dynasty. The Later Le Dynasty was founded by Le Loi. It is distinguished from the Early Le Dynasty (980-1009) founded by Le Hoan at the end of the 10th century. The Later Le Dynasty consisted of 2 phases: Hau Le Dynasty (1428-1527): lasted for 100 years, starting from the victory of Lam Son uprising, Le Loi rejected the puppet king Tran Cao, became king himself, established a new dynasty and ended when the power of the gods. Mac Dang Dung abolished King Le Cung Hoang and founded the Mac Dynasty. Le Trung Hung Dynasty (1533-1789): lasted 256 years, starting from when General Nguyen Kim established Le Ninh to the throne, (Le Trang Tong) to restore the Hau Le dynasty and ended when Le Chieu Thong fled to China. Living exile. How to call the Le dynasty Hau Le includes both Le so and Le Trung hung periods.

${ }^{3}$ Le So is the early stage of the monarchy dynasty Hau Le. This was the period when the totalitarian monarchy in the history of Vietnam reached the peak of its development as well as its decline for the first time. The Hau Le Dynasty was established after Le Loi launched the Lam Son Uprising to defeat the Minh Dynasty.
} 
Therefore, at present, there are too few documents to evaluate the development of education during the Mac Dynasty. For this reason, I have researched and rediscovered Confucian education and its role in Vietnamese society during the Mac period.

\section{Research content}

Education - faculty in Vietnam during the feudal period from the 11th century until the end of the 19th century the beginning of the 20th century was basically Confucian education and training. Therefore, the influence of Confucianism on the field of education - examinations is comprehensive, especially in the purposes, objects of education, content, educational methods, and methods of selecting talents. The impact of Confucianism and Confucian educational thought on Vietnam was evident from the Ly and Tran dynasties and flourished in the Le So dynasties. With the request to consolidate the centralized feudal state, under the Ly and early Tran dynasties (11th and 12th centuries), although not yet in a unique position, Confucianism was raised to the state religion. From the 13th century onwards, especially at the end of the Tran dynasty and the beginning of Hau Le, Vietnamese society and the Vietnamese state had basically reached the ripe feudal stage. Confucianism was brought to a unique position in the reign of Le Thanh Tong ${ }^{1}$. During this period, studying and taking exams under Confucianism flourished. The Mac dynasty followed the Le So dynasty to maintain the Confucian education - faculty and open regular examinations according to the regulations since the Le Dynasty, every 3 years. It can be said that, until now, no feudal dynasty has organized as many (total of 22) examinations as the Mac dynasty.

The education and examination system in the Mac dynasty was still basically following the Le So dynasty, for the following basic reasons: Firstly, because the Confucian education and training up to the Le So period with complete regulations. The strict and strict regulation reached its peak in the reign of Le Thanh Tong. Secondly, because the Mac dynasty robbed the Le house, in order to stabilize the people of the Mac dynasty, they had to follow the rules issued by the Le dynasty. Moreover, despite the constant war, the Mac dynasty still followed the old law of the Le dynasty, maintaining the opening of the Hoi exam every 3 years, which is a miracle in the history of education in Vietnam, which has never been achieved by any dynasty. This achievement was both the result and the cause of the maintenance and consolidation of the flourishing Mac dynasty for more than half a century. Through the content, teaching and learning methods, and the examination method to select talents and people to serve as mandarins, the basic requirements for passers-by are to have Confucian competence, profound knowledge of Confucian scriptures, know how to present their own opinions about that scripture, about the past and present times, must know how to bring that learning and apply it to life, to the work of helping the king rule the country and keep the people safe; must be fluent in Chinese culture and history, know how to write poetry, richness, processing, mating, expression... In general, the content of teaching, learning and examination in the Confucian education system of Vietnam under the Mac dynasty is basically Not only the knowledge in the scriptures, Confucian books. People who go to school, take exams, pass as mandarins, become teachers mainly to master that knowledge block. Educational methods also only stop at the traditional methods of Confucian education, without a strict and detailed system of methods for teachers and learners. However, those teaching, learning and examination methods have partly conveyed the essential and necessary educational content and guided learners how to apply it in real life, making a significant contribution to the success of the students. consolidating and developing the position of the Mac dynasty in the troubled social context at that time.

\subsection{The role of Confucian education in the Mac dynasty in the process of building and developing the central feudal state apparatus}

In the 16th century, after taking power from the Le So, the Mac dynasty (1527 - 1592) achieved brilliant achievements in national construction and development, especially in the early stages. With 65 years of existence, the Mac dynasty made Dai Viet a powerful country in Southeast Asia at that time in terms of economy, politics and culture - society. Dai Viet state was firmly consolidated and unified according to the model of a central feudal state, which centralized power and implemented the rule of the country and social management by law. Associated with the renovation and building of political institutions, the Mac dynasty paid special attention to building political people, focusing on training and using mandarins. As a result, the contingent of court officials as well as local mandarins has been increased in number, improved in quality in terms of qualifications, ethics and capacity, to promptly meet the requirements of the country's development. One of the jobs needed to create a bureaucracy that would serve as the social basis for one's dynasty was to open doctoral examinations. The organization of this exam was not for the purpose of building a feudal class loyal to the Mac dynasty, supporting

\footnotetext{
${ }^{1}$ Le Thanh Tong (August 25, 1442 - March 3, 1497) was the 5th emperor of the Later Le dynasty in Vietnamese history. He reigned from June 26, 1460 until his death in 1497, a total of 37 years, the longest-reigning emperor of the Later Le - early Le period in Vietnamese history. His period was marked by the flourishing of the Later Le Dynasty in particular and the Vietnamese feudal system in general with the name Hong Duc Thinh The.
} 
the existence and development of the Mac dynasty. When the new Mac dynasty came up, the aristocracy of the Mac dynasty at first did not play any role in the state leadership. The generation of intellectuals of the Le dynasty was disbanded, only a small part joined the government, and most of them fled, took refuge or remained in hiding. Meanwhile, descendants of the Le dynasty tried their best to resist. Therefore, the first and very important job of the Mac dynasty was to train a new class of intellectuals to supplement the state management apparatus. During the Mac Dynasty, together with the Confucianism gaining a unique position (although not as prosperous as the Le So period), The new Confucian election system was expanded, strongly developed and put into order. The development of exam education in this period was a favorable condition for the Mac dynasty to take the educational level as the basis for the selection of mandarins. The vast majority of bureaucrats at the central and local government levels and professional bodies have come from the faculty of education, who have passed rigorous examinations, regardless of their social background. (except for those who are banned from taking the exam). According to Dai Viet Su Ky Toan Thu ${ }^{1}$, Those who pass the exam with Tam truong ${ }^{2}$ are assigned to be the head of a district and those who do not pass $\mathrm{T}$ are only appointed as the leader of a district. There are even jobs that are not official of the court, but the selection is based on the basic criteria of being educated, This is the only way to do good work for the people. During the Mac Dynasty, village chiefs who were illiterate were dismissed. The Mac Dynasty wanted to create a mandarin apparatus consisting of elite people in the Confucian intelligentsia, carefully selected as a solid support for the court. Therefore, the class structure in the state leadership in the Mac dynasty was mostly Confucian bureaucracy selected by the bachelor's degree, the aristocracy of the family made up a very small number, the rest were a small number of intellectuals. old Le Dynasty.

The examination policy of Confucianism of the Mac Dynasty had a great influence on the Confucian scholars who were hesitant to decide to become a mandarin with the Mac or the Le-Trinh dynasty in the South. Even, Confucian education and training in the Mac period also attracted and entice Confucian scholars within the influence of the Le - Trinh dynasties. In the history of education and examinations in Vietnam, after the prosperous period of Le Thanh Tong (1460-1497), only the Mac dynasty (1527-1592) was able to continuously implement the sequential regulation every 3 years. Association exam. The number of examinations, as well as the quality of doctors under the Mac dynasty, are comparable to those of Le Thanh Tong. Most of the Dr and Trang nguyen ${ }^{3}$ selected by the Mac dynasty were talented people and made significant contributions to the history of the nation's culture, the most typical of which is Nguyen Thien, who was awarded Poinsettia in Nham. Thin (1532), Nguyen Binh Khiem, Poinsettia, At Mui (1535), Giap Hai, Poinsettia, Mau Tuat (1538), Tran Van Bao, Canh Tuat (1550), Pham Tran, Binh Dragon (1556). It is worth noting that after only 2 years of replacing the Le So dynasty and stationed the capital in Thang Long, the first king of the Mac dynasty (Northern dynasty) was Mac Dang Dung ${ }^{4}$ was able to open the contest exam to select talents and supplement the national administrative apparatus, contributing to strengthening the dynasty. Meanwhile, the Le - Trinh dynasties (Southern dynasties) didn't open Che Khoa until 1554. However, the opening of examination departments was not as regular as the Mac's. As for the contest, the festival was not organized until 1580, during the Le-Trinh dynasty. Thus, Confucian education and training played a very important role in building and consolidating the centralized feudal system. Thanks to Confucian education and faculty, the Mac dynasty trained mandarins and intellectuals for the independent feudal state apparatus for more than 60 years.

\subsection{The role of Confucian education in the Mac Dynasty in training talented people and building a learning society}

Unlike the dynasties established through glorious feats in the war of national liberation, or the feudal forces that once ascended the throne through bloody coups d'état and struggle for power, the Mac came to power after a smooth coup d'etat. Moreover, Mac Dang Dung ascended to the throne from the position of being a martial officer, not a well-trained person from the Confucian academic background. Therefore, right after ascending to the throne, Mac Dang Dung established the necessity of the Mac dynasty to replace the corrupt Le so court, which was in crisis under the reign of the evil kings, the Heo king by clever ways. re-use the team of intellectuals of the Le dynasty and maintain the legal status of the Le so dynasty, and at the same time pay special attention to the election system to select talents. However, in fact, the Mac dynasty still received the support of a large number of intellectuals, including those who had worked as mandarins for the Le dynasty or trained under the Le dynasty such as Pham Gia Mo, Vu Ho, Le Quang Bi...

\footnotetext{
${ }^{1}$ Is a history written in Chinese literature of Vietnam, recording Vietnamese history from the legendary period Kinh Duong Vuong to 1675 during the reign of King Le Gia Tong of the Hau Le Dynasty

${ }^{2}$ Means pass the first three rounds.

${ }^{3}$ Is a title belonging to the doctorate degree of the person who got the highest rank in feudal exams in Vietnam.

${ }^{4}$ Mac Thai To (November 22, 1483 - September 11, 1541), whose real name is Mac Dang Dung, was a politician and emperor who founded the Mac Dynasty in Vietnamese history.
} 
Education - Faculty of Confucianism during the Mac period created a contingent of mandarins for the imperial apparatus, and at the same time "produced" a lot of talents for the country, including many very famous people such as Nguyen Binh Khiem, Giap Hai, Ha Nham Dai, Hoang Si Khai, etc. Or those who didn't pass but also became famous Confucians like Nguyen Du... The educational system of the Mac dynasty also created a contingent of Confucianists. numerous intellectuals in the villages and communes; Since then, the Literary Society was established. They had a great influence on the construction of local feudal traditions. The policies of inviting sages and entertainers of the court, the village conventions, folklore genres, etc. showed that the feudal dynasties of this period attached great importance to learning. Most of these talents come from hard-working families, clans, and villages with a long tradition of studious, love, and hard work. In 1529, Mac Dang Dung also followed the custom of promulgating the 15th year of Hong Duc (1484) under Le Thanh Tong's reign, to set up a stone stele, to honor those who were elected to Dr. But then because of the constant war, the erecting of the stele was not carried out regularly. In 1852, Thieu Bao ${ }^{1}$ Tran Thi Tham offered to continue erecting a stone stele to promote the exam, but it was not possible. Therefore, today, of the remaining 82 Doctoral steles in the Van Mieu - Quoc Tu Giam², there is only one stele that records the Hoi exam in 1529 under the reign of Mac Dang Dung. However, only the first paragraph of the exam paper that year also shows the bustling atmosphere in Thang Long due to thousands of candidates from all over the country flocking to take part in the exam: "Meet the year of Hoi, ... came to the capital with over 4,000 people to compete in literature at the competition school. Officials selected 27 excellent people". "In 1536, Mac Dang Doanh ${ }^{3}$ ordered to restore the Temple of Literature. The following year, the work was completed, Mac Dang Doanh offered incense at Văn Mieu and visited the ergonomic house." .

At the same time, the Mac court paid great attention to the policy of treating talented people. That also became the motivation for the soldiers and encouraged the people's studious spirit. Because the spirit of studiousness is the product that reflects the process of individuals and society in historical periods that emphasize learning and the path of advancement through education. The influence of the spirit of Confucianism on education in this period is very clear. Confucian thought about "reputation" has urged people to strive, study hard to wait for the exam date. The purpose is not only to be a mandarin, but also to honor the family, to shine for the ancestral family. The role of education - Confucianism had a great influence on the education and examinations of the Mac dynasty in both positive and negative aspects.

First of all, Confucian education and training in this period motivated the people of Dai Viet under the Mac dynasty to study hard. The policy of paying attention to education - the Confucian faculty of the Mac dynasty made the learning movement in the capital Thang Long as well as in the localities within the Northern dynasty's domination of the learning movement. People race to learn, families race to learn. The system of schools, the system of references, and the curriculum in the spirit of Confucianism during this period became richer and more systematic. The policy of paying attention to education has motivated people to race for their children to study from a young age. During this period, many famous Vietnamese people were mentioned such as: Trang Trinh Nguyen Binh Khiem ${ }^{5}$ (1491 - 1575), Duong Van An (1513 - ?), Giap Hai (1515 - 1585)... Although the country happened wars between the North and the South, but the learning spirit of the whole society in this period did not decrease. Examinations held by the imperial court are still held every three years. In the early years, especially during the reign of Mac Thai Tong, that spirit of learning became more and more exciting.

However, looking back on the historical journey that the Mac dynasty went through, besides the achievements that the Mac dynasty had achieved, there were also limitations due to the negative side of the socio-historical situation at that time. It is still a society with the spirit of learning to help the king rule the country, but in fact it has been perverted by the attraction of money, by the vortex of fame and profit. In the early years when Mac Dang Dung built the government, at that time, society was prosperous, people's lives were prosperous, peaceful, socio-economic development was outstanding. But later on, especially after the NorthSouth war between the Mac and Le dynasties, Trung Hung, the kings and mandarins in the court were in turmoil, the servants abused their power, the society was in crisis, and the people were safe. they are threatened. Also during this time, the feudal system went into decline, feudal corporations had fierce conflicts of interests, competing for power by mutual wars. All of this has made Confucian ideology increasingly degraded and disintegrated. "The principles, moral standards, and feudal rites are only a cover, just a form. In terms of education, the rules on examinations are stricter, forcing students to only lean towards learning from cliche

\footnotetext{
${ }^{1}$ High position in the feudal court.

${ }^{2}$ Van Mieu was built in 1070 during the reign of King Ly Thanh Tong. This is considered the first school in Vietnam.

${ }^{3}$ Is Mac Thai Tong (? - January 15, 11th Dai Chinh year (1540) is the 2nd emperor of the Mac dynasty in Vietnamese history.He was crowned king from 1530 to 1540 , a total of 10 years.

${ }^{4}$ Nguyen Tien Cuong (1998), The development of education and the examination system in feudal Vietnam, Education Publishing House, Hanoi, p.102.

${ }^{5} \mathrm{He}$ is one of the most influential figures of Vietnamese history and culture in the 16th century, the Le - Mac war. After being elected to the post of trang nguyen in 1535 and serving as a mandarin under the Mac dynasty, he was awarded the title of "Truong Tuyen Hau" and then promoted to "Trinh Quoc Cong", so people used to call him Trang Trinh.
} 
chapters, practice tricks, ways of sharpening literature, pruning every sentence and word without going. depth of thought. Later, students read less and less thinking... ${ }^{1}$. Due to the limitation of such a number of books, compared to before, the number of people studying the meaning of the book is more, the study is expanded more widely, the number of people who pass the exam achieve the tribute, the student's map is also larger, but very few people have profound erudition, the number of people who pass high in the Dinh exam is also less. This decline in quality is due to the corruption of contemporary politics, due to turning the former strict election into a place to trade honors, buy and sell mandarins. Cheating during exams, when marking exams, eating, bribing, protecting students to pass becomes a regular thing.".

The purpose of the person taking the exam at this time is to pass the exam to become a mandarin, have conditions to exploit the people, flatter the power, benefit individuals and their families and clans. History books record many doctors of this period such as Nguyen Tuan (1562 - ?), Nhan Muc, Thanh Tri, Nguyen Lai (1581 1661), Bot Thuong, Thanh Hoa ... openly bribed and offered bribes. upper lining. Others are in league, factions are partying. Nguyen Binh Khiem felt disgruntled at the scene of his courtiers' abuse and offered to cut 18 corrupt officials. "It can be seen that, from the Mac dynasty onwards, especially at the end of the Le, the Confucian sects no longer maintained their ethereal character and virtuous behavior, most of them were only literate, self-interested and trendy people. It is because of that selfish interest that most Confucianists have not seen the domination of feudal groups that are decaying, corrupt, unable to grasp the times, and clinging to the concept of "ngu trung ${ }^{2}$ ". On the socio-political level, the basic ideological content of Confucianism is the doctrine of "just name and destiny" in order to strengthen and protect order, caste, and maintain feudal hierarchy. But at the end of this period, the principles of feudal etiquette were undermined. The relationship between king me, teacher - disciple, loyalty - patriotism... all seriously disintegrated. They study not for the sake of learning, but for the sake of degrees, fame, and titles. The magical attraction of money in the late Mac society has perverted the beautiful image of a prosperous feudal society in the spirit of Confucianism.

Thus, Confucian education and training in the Mac dynasty played an extremely important role in training talents and building a learning society, especially in the early Mac dynasty. However, the spirit, attitude and learning purpose of the cadets have decreased over time, moving away from politics, pursuing degrees and selfinterest. After all, that situation was also determined by socio-economic conditions and social existence at that time.

\subsection{The role of Confucian education in the Mac dynasty in perfecting social morality and developing Dai Viet culture}

Confucianism was introduced to Vietnam and accepted by the Vietnamese, who emphasized the letter "hieu"3, upheld filial piety, chastity, protection of the family, clan, and clan. Among the 10 crimes, the sin of being unfilial heaviest. Education - Confucianism in the Mac Dynasty played a very great role in forming relationships in the family and clan, building the family style in which the letter "hieu" is the first for children. letter and the letter "tiet hanh" for the female head. The Mac Dynasty emphasized morality and ethics, emphasizing that the human way is the Five Wheels (King - me, father - son, husband - father, brother - brother, friend - friend). The Mac Dynasty also gave the noble title "Tiet hanh kha phong", "Hieu hanh kha phong". Confucian education and training in the Mac dynasty had great merit in strengthening the bonds between individuals and between families according to Confucian ethical criteria. The order of Confucianism is hierarchical, consisting of 9 systems (nine clans). The family has a relationship with the clan, the clan strengthens the family by beliefs, family rituals, family training, family style, clan conventions, kinship rules, genealogy, family church... The feudal state strengthens the bond between clans and clans with positive factors, upholding the bloodline of Dragon and Fairy descendants, Lac descendants of Hong.

During the Mac Dynasty, Confucian education and training was very popular, so it greatly influenced the concept of the role and position of the teacher. The teacher has a game to grow not only in imparting Confucian knowledge, but moreover, in teaching the word "righteousness", the word "human", and educating "moral" for learners. Under the Mac dynasty, the legal system was arranged with legal provisions. Learners must be polite to their teachers, professionals must set an example for learners to talk to. Under the Mac dynasty, the law - the game was always appreciated and focused. Society dictates that parents must arrange their children morally. When a teacher teaches, there must be respectful, polite, not allowed to disobey orders; Otherwise, it will be added to the crime of disrespect. Students must respect the teacher, study hard, take morality as the root, must

\footnotetext{
${ }^{1}$ Nguyen Đang Tien (Ed, 1996), History of education in Vietnam before the August Revolution 1945, Education Publishing House, Hanoi, p.108.

${ }^{2}$ Nguyen Đang Tien (Ed, 1996), History of education in Vietnam before the August Revolution 1945, Education Publishing House, Hanoi, p. 110 .

3 "Hieu" in the concept of Confucianism has quite rich content. First of all, it is the son who has to take care of his parents when they are old and worship them when they die.

${ }^{4}$ A woman's loyalty to her husband.
} 
not look down on the teacher, anyone who disobeys the order will be punished. It is that thought that has become the foundation in establishing order in society, especially in the teacher-student relationship. If a teacher can teach well, many students will come to study. The subject council mobilizes students' families to contribute money to create fields, create buffaloes and cattle, and then assign them to plow and reap. When the harvest comes, the teacher's family can pay for it. When the teacher died, he used that field to take care of the funeral for him, his wife, and the anniversary of the New Year and later sacrifices. Students mourn for the teacher for three years like their parents, but they do not wear mourning clothes, which is called the heart mourning, which means mourning in the heart. Since ancient times, "respecting the teacher" has always been a good communication foundation of the Vietnamese nation. Teacher is a typical image of noble values, in the light of morality and human personality. In "Tam cuong"1, his position is only below the king and above the father. The owner of the class, has a great breadth of knowledge and personality. The teacher's function is not simply to impart knowledge, but also to serve as a role model for the director. Under the feudal dynasties of the Mac dynasty, many talented teachers were appointed as military advisors by the venerable family, they participated in the main dynasties and made great contributions to the country, such as Nguyen Binh Khiem. He was adopted by his student, Tuyet Giang. Bach Van Am school of Nguyen Binh Khiem is famous for creating excellent games, such as: Phung Khac Khoan, Luong Huu Khanh, Nguyen Du...

Along with the economic and political developments, from the 16th century onwards, especially since the Mac dynasty was established, the culture bearing the national identity of Vietnam developed strongly and achieved great success. brilliant achievements. Although the Mac Dynasty emphasized education and training in Confucianism, it was not as unique as Confucianism as in the Le So era. (In the Le Dynasty, especially during the reign of Le Thanh Tong, Confucianism became a monopoly and totalitarian ideology, so folklore was ignored. Even King Le Thanh Tong banned the performance of art forms. folklore such as rowing, tuong in the royal court). Besides Confucianism, the Mac Dynasty made many efforts to restore Buddhism and promote the traditional culture of the nation, and at the same time cultural exchange with the surrounding regions. Scientists have assessed that the culture (mainly Dai Viet culture) at that time not only absorbed and was influenced by the general culture of the region, which was the culture on the basis of Confucianism, but on the contrary it was developed to a higher level than the culture of the surrounding countries at the same time, contributing to the enrichment of the culture of Southeast Asia. It is the cultural exchange, through the missions of famous Vietnamese celebrities with the Chinese court and the envoys of neighboring countries (such as Korea, Japan). The literature of the Mac dynasty is a period of Vietnamese literature that reflects the achievements in literature and poetry of Dai Viet under the Mac dynasty from 1527 to 1592. This field is also the result of Confucian education and training. learn. Literature of the Mac Dynasty also made many contributions to Vietnamese literature. In addition to new works, this period is also credited with re-collecting previous works lost due to war. Literature of the Mac Dynasty - a period of turmoil and war is also very rich: in volume 5 of the Collection of Vietnamese Literature (all 42 volumes), a total of 19 authors were listed. That is not to mention a number of other writers and poets who are classified in the section "Authors of the Le so dynasty, early Mac dynasty". The collected works so far have a total of more than 100 works of poetry, large and small. It was also one of the products of the Confucian education and training in the Mac Dynasty. According to Le Quy Don ${ }^{2}$, the literature of the Mac dynasty is divided into three main genres: the first is the Charter: typically Giap Hai (the work Responding to diplomacy); the second is Poetry: typically Nguyen Binh Khiem (a collection of Nom Bach Van Quoc Ngu poems), Ha Nham Dai, Nguyen Gian Thanh, Pham Thien, Hoang Si Khai, Nguyen Hang, Bui Vinh (a collection of Cung Trung Bao Tuong). The genre of psalm poetry of the Mac dynasty was quite developed with new themes. Instead of the popular court praise genre under Le Thanh Tong's reign, it was a collection of poetic poetic fields, secluded with nature; the third is Tales of Tales: typically Duong Van An (O Chau can Luc) and Nguyen Du (Truyen Ky man Luc). Among the above authors, the largest is Nguyen Binh Khiem - who is considered as a great tree of the 16th century. He composed thousands of poems, of which the Nom script accounts for a significant number, and more than 100 are still preserved. . His Nom poetry marked the development of the Vietnamese language. Nguyen Binh Khiem's poetry has rich content, reflecting many aspects of social life, condemning war and bad habits in life.

The genre of poetry in the Mac dynasty was quite developed with new themes. Instead of the genre of court praise popular under Le Thanh Tong's reign, is a piece of poetic richness, reclusive with nature, representing this trend is Nguyen Hang with Đai Đong phong canh phu, Tinh cu minh the phu; Hoang Si Khai with Tu thoi khuc vinh, Nguyen Gian Thanh với Phung Thanh xuan sac phu. Among the poems of the gulf period and the poetry of porcelain, the most typical works are: Giap Hai's Vinh beo is considered a good poem against China's invasion intentions. Le Quang Bi's collection of poems Tu huong van luc for 18 years was kept in China by the Minh

\footnotetext{
${ }^{1}$ The three relationships of morality in feudal times, in the past in Vietnam, were: king and people, father and child, wife and husband.

${ }^{2}$ Le Quy Don (August 2, 1726 - June 11, 1784), at a young age named Le Danh Phuong, was a mandarin of the Le Trung Hung period.
} 
Dynasty to show his love for his homeland. Khieu vinh thi tap by Ha Nham Dai has a bold and accurate critique of political figures.

The narrative genre in Vietnam was born quite late: Before the Mac dynasty, there was only Viet dien u linh by Ly Te Xuyen and Linh nam chi quai of Tran The Phap. During this period, two major works were recorded: Duong Van An's O Chau Can Luc and Truyen Ky Man Luc by Nguyen Du. O chau can luc became an important source for Le Quy Don to supplement the book Phu Bien Tap Luc. As for Nguyen Du's Truyen Ky man Luc, edited by Nguyen Binh Khiem, it had a great influence on contemporary literary life and the author was praised for having a strange pen. Besides the development of literature, the art of the Mac dynasty also had equally brilliant achievements. Art of the Mac period has a full range of forms such as architecture, sculpture, ceramics... mainly in the field of architecture and decoration, reflected in works in the palace, temples and villages. remains to this day and is reflected on the epitaph. The important royal works of the Mac dynasty were mainly in Duong Kinh (the current relic is in Co Trai, Kien Thuy district, Hai Phong city) - the homeland of the Mac dynasty such as Phuc Huy Palace, Hung Quoc Palace, and Sung Duc Palace. From the Mac Dynasty, the communal house was used as a place for community activities. The two most famous communal houses of this period are Dong Lo and Tay Dang. The architectural and decorative arts of the Mac dynasty are considered to have created a major turning point in the history of Vietnamese art. Thus, although Confucian education in the Mac dynasty did not achieve brilliant achievements like that of Le Thanh Tong's time, it also contributed significantly to building morality, maintaining social order and developing the Vietnamese economy. Dai Viet culture in the 16th century.

The above are the results of Confucian education since the Mac took power. Although in the end it was governed by social existence, but at the same time, that education and examination also had an impact, making a significant contribution to the establishment and consolidation of the Mac dynasty in all fields. region for more than 60 years and has had positive effects on the development process of the Vietnamese nation. Experiencing many ups and downs of history, Confucian education in the Mac dynasty still has great impacts on the education and training cause of Vietnam today. This is reflected in both positive and negative aspects.

\subsection{Values that should be inherited from Confucian education in the Mac Dynasty}

First: Viewpoints, mottos and educational content

The first lesson is drawn from the Confucian education and training in Vietnam under the Mac dynasty, which is to inherit the motto and strategy of education and training for people. According to Confucianism, one of the basic purposes of education and training is to train the ideal type of person for society - the gentleman - people who have enough virtue, enough talent, benevolence, righteousness, courtesy, wisdom, trust... and capacity to build an ideal society. They are comprehensive people to help the country and help the people. The purpose of studying Confucianism is not only to become a mandarin to enjoy benefits, glory, and fame, but mainly to bring his talents and wisdom to help the country, the people, serve and protect the regime. centralized feudalism. Confucian education in the Mac dynasty considered the education and training of people to be the focus, starting point, goal and driving force of social development. Acquiring this point of view from Confucian education, in the cause of building and defending the Socialist Vietnamese Fatherland, Ho Chi Minh ${ }^{1}$ raised his strategic thought on human education and training: "Want to To build socialism, first of all, there must be socialist people".

Confucian education in the Mac dynasty paid great attention to the training of mandarins to serve the feudal system. The educational motto of Confucianism in general, of Vietnamese Confucian education in the Mac dynasty is that people who have served as mandarins must be educated, trained, and have real talents. This is also the lesson that today's Vietnamese need to inherit. In particular, in the current situation in Vietnam, there is still quite a common situation of buying positions and buying rights of a part of the leadership team at all levels; the state of being a mandarin and then going to school, not studying to be an official as the purpose of education - the Confucian faculty.

Confucian education in the Mac dynasty paid special attention to moral education - education of "doing people" - training ideal people, developing comprehensively, not only having talent but also having to have morality in order to be able to meet the needs of people. win people's hearts, set an example for the people to believe and follow. That education considers moral education and personality formation as the central issue. After all, education is a contribution to the formation of personality, in which morality is the root and also the noble purpose of the cause of education. This lesson is still valid in the education and training of cadres in the current Vietnamese government apparatus. Because leaders have good moral qualities, benevolent, and meaningful to make people believe and follow. Therefore, the cause of education and training in Vietnam today, besides equipping and improving knowledge for people, especially cadres and party members, it is necessary to

\footnotetext{
${ }^{1}$ Ho Chi Minh (May 19, 1890 - September 2, 1969), the birth certificate is Nguyen Sinh Cung, he was a revolutionary, the founder of the Communist Party of Vietnam, served as Prime Minister of Vietnam South Democratic Republic of Vietnam in the years 1945-1955 and was the President of the Democratic Republic of Vietnam from 1951 until his death.
} 
foster moral qualities, attaching importance to moral education is both a prerequisite and a long-term goal in the human training strategy.

In summary, the Confucian education of the Mac Dynasty with the above viewpoints, mottos and educational contents, after all, is also aimed at equipping the theoretical ideology to serve and protect the feudal regime. centralization of power. This lesson is still valid with the education of Vietnam today, in equipping the Vietnamese with Marxist-Leninist theory and Ho Chi Minh thought to contribute to the cause of building and defending the Vietnamese regime. socialism and defense of the Fatherland. Second: Method of education

In recent years, in Vietnam, educators, leaders, parents and school-goers are very interested in educationtraining methods in general, and teaching-learning methods in schools. levels in particular. Because the method of education and training in Vietnam still has many shortcomings and backwardness, it requires a step-by-step and reasonable innovation to improve the quality of education and meet the development requirements of the country, society. The educational method system of the Confucian education of the Mac dynasty also left valuable lessons for the current Vietnamese education.

The method of private learning combined, learning coupled with deep thinking will help make the most of learners, helping learners to know how to rely on the teacher's suggestions without constantly expanding and enriching the what was learned. This method helps learners not only grasp the content of the lecture faster, but also create habits, bravery and self-study and self-study methods of learners.

The method of evoking, two-way dialogue between the teacher and the learner has the effect of maximizing the dynamism and creativity of learners. This is a process of interaction and mutual learning between the teacher and the learner, not a passive, one-way reception like the reading-copying method that exists quite commonly in schools today. Acquiring this lesson for the current educational method will contribute to training the positivity, initiative and creativity of learners, creating a class of people who actively adapt to the market mechanism and respond well to real needs. of the country.

In particular, in the current conditions of Vietnam's national renewal, it is extremely necessary to apply the learning method along with the practice. In schools in Vietnam today, teaching - learning is still heavy on theory and light on practice, so as a result, it has created many dogmatic people who are difficult to adapt to the demands and changes. ceaseless of practice.

In the system of traditional education methods Confucianism in the Mac dynasty, there is also a method that is extremely important for Vietnamese education today, which is the example method. This method is especially important because it has a strong impact on the learner's consciousness by the teacher's own example. The teacher is not only a person who imparts knowledge but also has to be a bright example of moral cultivation for students to follow. The teacher's shining example plays a role in strengthening the confidence of the learners, becoming the driving force to help the learners progress faster. Not only stopping at demanding, asking the teacher to be an example for students, but in the Confucian education of the Mac dynasty, it also set the example of the ancients, taking the example of sages, national heroes... to set an example and model for the next generation to follow. Thereby, laying the basis for traditional education in human education and training. In the current situation of Vietnam, when the manifestations of the deterioration of moral qualities of a part of the teaching staff are increasing, the research back to traditional education, understanding and applying Using the example method is very necessary and meaningful. Among the educational methods that Vietnam is applying today, there are still ways of teaching and learning that stifle people's thinking ability and creativity, making it difficult for them to adapt to life is changing. If you know how to combine the use of traditional educational methods in Confucian education with modern educational methods, it will contribute to creating useful people for society, meeting the requirements of the times. Therefore, it is extremely necessary and meaningful to study Confucian education in the Mac Dynasty, thereby drawing lessons that can be inherited and determining the methods in Vietnamese education today.

Third: The issue of training, fostering and using talents

Lessons on the issue of training, fostering and using talents in the education and examinations of the Mac dynasty are still valid for the development of Vietnamese education today. During the Mac Dynasty, the selection of talents for the country was mainly based on the election. That became one of the driving forces promoting the tradition of studiousness of the people in this period. The dynasties are clearly aware of the role of talent: the use of talents is decisive for the prosperity of the nation. Therefore, the use of talents is the "first thing" in the way of governing the country of the Mac kings, especially in the context of chaotic wars, competition for influence of the Le - Trinh factions, Nguyen.

In short, the Vietnamese education and examinations under the Mac dynasty left many valuable lessons, contributing to building an advanced and modern Vietnamese education, but still imbued with national identity. However, absorbing and inheriting the values of Confucian education in the Mac period requires us not to be stereotyped and mechanical, but to apply it flexibly, depending on the period, there are changes to suit. 


\subsection{Lessons learned from the limitations of Confucian education in the Mac Dynasty}

Facing the current situation of Vietnamese education, in order to build a comprehensive, advanced, humane and effective education, we must know a harmonious combination between traditional and modern factors. Studying back to Confucian education in the Mac Dynasty as a traditional factor in the formation and development of Vietnamese education today, requires us to adhere to the principles of the materialist worldview. correct dialectic of Marxism - Leninism, Ho Chi Minh thought. We see that, in addition to the positive values of Confucian education, which is also meaningful to the development of education today, there are still outdated and outdated factors that hinder the development of modern education. and improve Vietnamese education. Therefore, along with the identification of positive and valuable factors, it is extremely necessary to find outdated and outdated factors to resolutely eliminate them.

Firstly, the Confucian education of the Mac Dynasty in educational purposes, besides the positive side, also left consequences in the way of thinking of many people who conceived of training people to become rulers in society. . The path of a gentleman in a feudal society is to go to school to take an exam, to take an exam to pass, to pass and then to become a mandarin. Since then, it has led to the perception that is very harmful to the development of society that Confucianism is very contemptuous of occupations and manual labor; they consider it to be poor jobs.

The fact that Vietnam's education system in recent years also shows that people are still affected by that mentality. The evidence is that the number of students graduating from high school applying for entrance exams to universities and colleges is very large compared to the number of candidates who aspire to go to intermediate and vocational schools. This situation has created an imbalance between training professions in the educational career of Vietnam, creating a reality of an excess of teachers but a shortage of workers. Therefore, it is required that we create realistic social foundations that can effectively overcome the mentality of disregarding vocational training that is deeply rooted in the subconscious of Vietnamese people.

Second, the Confucian education of the Mac dynasty along with the selective selection of talents for the country also left heavy consequences in the psychology of teachers, students, and students. Because the purpose of Confucian education is mainly to serve the ruling class and learn to be a mandarin, negative factors are increasingly crept into the official places and into people's lives. Later, especially in the second half of the 16th century, people worried about studying not for the sake of learning, but away from it, learning just for the sake of status, for benefits, for being able to exploit others. Currently, the Vietnamese call it: "achievement disease" - the way of teaching and learning is mainly aimed at achieving results in the entrance exam; degree psychology. This is also a real lesson that is painful in Vietnam's education today.

In addition, Confucian education in the Mac dynasty also contributed significantly to the process of creating backward customs and practices such as patriarchy, respect for men, education with rods, etc. and still exist. persisted throughout history, even affecting even today. These limitations need to be resolutely overcome and soon eliminated. In short, the values of education and examinations in the Mac period have great significance for the current Vietnamese education. On the one hand, it is the foundation for us to inherit and promote the positive values of the Confucian spirit in education and examinations, in the training of cadres for the country. In addition, it also shows that the echoes of the "please give" mechanism still persist in the current Vietnamese society.

\section{Conclusion}

Confucian education in Vietnam during the Mac dynasty played a huge role in the process of building and developing the centralized feudal state apparatus, affirming the necessity of the Mac dynasty to replace the Le dynasty. has rotted; in training talents and building a learning society; as well as in building and perfecting human and social ethics. In addition, education - Confucianism also plays an important role in contributing to promoting the brilliant development of Dai Viet culture. The development of Confucian education and training has contributed mainly to stabilizing the socio-economic situation in the area under the Mac's control, especially in the early stages of the Mac dynasty. In the current condition of building Vietnamese education, it is necessary to inherit valuable elements from the Confucian education of the Mac Dynasty in the motto, purpose and content of training a comprehensive, qualified human being, talent enough; Knowing how to combine the use of traditional educational methods in Confucian education with modern educational methods will contribute to creating useful people for society, meeting the requirements of the times.

\section{REFERENCES}

1. Phan Huy Chu (1992), Lich trieu hien chuong loai chi, 3 volumes, Social Science Publishing House, Hanoi.

2. Quynh Cu, Đo Đuc Hung (1995), Vietnamese Dynasties, Thanh Nien Publishing House, Hanoi.

3. Đai Viet su ky toan thu (2004), Volume 2, Culture - Information Publishing House, Hanoi.

4. Le Quy Đon (2007), Đai Viet thong su, Publishing House of Culture and Information, Hanoi. 
5. Trần Văn Giàu (1993), The development of Vietnamese thought from the 19th century to the August Revolution, volume 2, Ho Chi Minh City Publishing House.

6. Nguyen Thi Chan Quynh (2003), Faculty of Education Vietnam - upper book - Thi Huong, Literature Publishing House, Hanoi.

7. Nguyen Huu Tam (1991), "The situation of education and exams in the Mac Dynasty", History Research Journal, No. 6, pp.28-32.

8. Ngo Đuc Tho (Ed, 2006), People who got high marks in exams held by the feudal court in Vietnam, Literature Publishing House, Hanoi

9. Nguyen Đang Tien (Ed, 1996), History of Vietnamese education before the August Revolution, 1945, Education Publishing House, Hanoi.

10. Vietnam Literature Collection (2000), Volume 5, Social Science Publishing House, Hanoi.

11. Cao Tien Trai (1969), Le trieu tinh khoa Tien sĩ, Book 1, Education Publishing House, Hanoi. 